\title{
Revisiting the Peace-Building Efforts in Post Conflict Niger Delta, Nigeria: A Case Study of the Amnesty Programme
}

\author{
Imongan Ernest Omokhoa \\ Centre for Population and Environmental Development, Benin City, Edo State, Nigeria \\ Email: imonganernest@gmail.com
}

\section{Doi:10.5901/mjss.2015.v6n6s1p349}

\section{Abstract}

This paper intends to examine peace building efforts in post-conflict Niger Delta. The conflict which has affected oil production in Nigeria. This is also because oil is the main stay and a major source of energy in Nigeria. The study tends to look at the method, causes and assessment of the amnesty programme. The study covers a time frame between 2009 to 2015 . The qualitative method is adopted and the use of secondary data will be employed for data generation and analysis as well. This study will reveal individual or group involved in the conflict. It will further proved that persistent neglect, deprivation and marginalization without development or compensation, high level of unemployment, environment degradation, uneven resource distribution and lack of basic amnesty. It was these problems that led to the emergence of militancy in the region for the past years. The study also reveal an attempt made by successive Nigeria Government to establish different commission to look into the Niger Delta issue, the DDR programme, security implications and its challenges in the Niger Delta clearly indicate that until the root cause of the region is achieved there will not be enduring peace, security and stability in the environment.

Keywords: Conflict, DDR, Militancy, Niger Delta and Peace building.

\section{Introduction}

The implementation of the amnesty programme since 2009 has brought much gains to Nigeria. This is because of the increase in oil production (Ajayi \& Adesote, 2013). Before amnesty, oil production was as low as 700 thousands barrel per day now, it has increased to 2.6 million barrel per day (Jegede, 2013). The programme is timed within the period of 2009 to 2015 is to bring lasting solution to the lingering crisis in the region. In addition, after five years of it implementation it has also brought about stability in the environment.

Prior to the amnesty, there was violent agitation by the people due to resource distribution. In spite of the wealth from the oil bearing area, the Niger Delta region still remain underdeveloped and crisis prone in Nigeria as there is no infrastructural development. They felt they have been marginalized and the resources exploited without any compensation or meaningful development for their God given wealth. Thus it serve as the nation's economic jewel and its central to development. However, it remains improvised as it is the goose that lay the golden eggs with about 600 oil field, $75 \%$ oil capacity production and $90 \%$ of foreign earnings (Aghedo, 2013).

Besides, major actors in the conflict are government, oil companies and restive youths (militants) the latter which have suffered untold hardship and are living in abject poverty. This was as a result of the negligence, deprivation, lack of social amenities, unemployment, underdevelopment and oil exploration on government part as the youths felt they were deprived they decided to take their destiny in their own hands and took to militancy. The region's agitation for fair distribution of resources was left unheeded as the region became volatile which subsequently turned into an arm struggle because of these grievances, there was violence.

This is so because the agitations and struggle began in the 1960s with protest, demonstrations to mention but a few. By the year 1990 onwards it continued with some environmental and minority rights activists during which they made appeal to the Federal Government and oil companies in developing the area fell on deaf ears, as government and oil firms did little or nothing to ameliorate the plights of the people. Similarly, this gave rise for the emergence of militants groups such as the Movement for the Survival of the Ogoni People (MOSOP) and to an extent the Movement for the Emancipation of the Niger Delta (MEND) while some were ideologically or economically driven others were propelled by greed and excessive desire even though they stressed grievance in their narrative (Aghedo, 2013). Since then, militants in the region disrupted oil production and adversely affected the economy. In 2014, it has taken a different twist with the Niger Delta Volunteer Force (NDPVF) led by Alhaji Mujahid Asari Dokubo (Ike, 2013). Since then, it has evolved from complaints against environmental degradation to alienation and youth militancy and finally to open armed rebellion. The 
militias, armed youth and criminal gangs have transformed the Niger Delta in a bad light into a region of anarchy and lawlessness.

These groups have perpetuated various acts of criminality as such and engage in abduction and hostage taking of oil firm personnel including (expatriates) for ransom before release. It later escalated to pipeline vanderlization, armed robbery, bombings, oil theft and sea piracy amongst others (Aghedo, 2013). Government Tompolo, one of the leaders of a militia group, is said to have amassed a personal fortune from bunkering. According to a report published by the Niger Delta Technical Committee (NDTC) made up of a-45-person body was established by Nigerian government to seek solution to the conflict shows that during 2008 alone, 300 hostages were taken; about 1,000 people are estimated to have been killed in violence related to militants activities (Olukoya, 2009).

In order to effectively minimize the impact of violent conflict on the economy, by June 25 2009, the Yar'Adua administration took a bold step to peace building and declared unconditional pardon to the repentant ex-agitators. The amnesty pogramme which came up in 2009 will be six years in October 2015 and huge amount of money have been spent on it. Despite various efforts by successive government to resolve the conflict what is experienced in the region is a peace of the grave yard. Yet, to what extent has amnesty and peace building brought about a secure and stable environment? What effects is the amnesty programme? What are the security implications? These questions need to be explored.

\section{Objectives}

In this study, an attempt is made to critically analyze the government sponsored amnesty package as a last resort, its impacts, assessment, DDR and revisiting the peace building efforts in post-conflict Niger Delta:

- The Amnesty Programme

- Critical Assessment

- Impact of Amnesty Programme

- The DDR programme in Post-Conflict Niger Delta

- Revisiting the Peace Building efforts in Post-Conflict Niger Delta

- Security implications of the Challenges

- Government Efforts in Niger Delta

\section{Methods}

The study revisiting the peace building efforts in post conflict Niger Delta, Nigeria is agreeable contemporary. In recognition of this fact, it is relevant to consider ex-militants activities and its phenomenon which have bearing on the subject matter. The method is qualitative and explanatory in nature. This method is adopted because it is an excellent way of collecting information/data for easy understanding and interpretation.

\section{The Amnesty}

One major achievements of the late Yar'Adua administration is the presidential pardon to ex-combatants. The government acknowledges the problems that arose from the inadequacies of previous government in an attempt at meeting their demands and aspirations put in place the needed machinery for such programme in the region (www.businessdayonline.com).

The Federal Government of Nigeria granted an unconditional pardon to all persons who have directly or indirectly participated in the commission of offences associated with militants activities in the region, see (dlc.dlib.indiana.edu/ 2015). The amnesty package proclaimed was expected for a 60 day period from August 6th to October 4th, 2009. Within this period, opportunity was given to ex-militant in the region to surrender their arms and ammunitions in exchange for presidential pardon.

The declaration of the Federal Government amnesty was welcomed by a large section of the society and groups, including several international bodies pledge their supports for the programme. Though, the securing of lasting peace in the crisis prone region has not been an easy task. According to Aghedo (2013), as part of his efforts, Late President Musa Yar' Adua offered state pardon to the militants and as noted by Kuku (2012) that:

"The offer of amnesty is predicated in the willingness and readiness of the militants to give up all illegal arms in their possession completely renounce militancy in all its ramifications unconditionally, and depose to an undertaking to this 
effect. It is my fervent hope that all militants in the Niger Delta will take advantage of this amnesty and come out to join in the quest for the transformation of our dear nation".

\section{Critical Assessment of the Amnesty Programme}

With the amnesty programme initiated by the Federal Government, designated centers were allocated in six Niger Delta states namely; Akwa Ibom, Bayelsa, Cross River, Delta, Edo and Rivers state respectively (Watt, 2011). Importantly, as soon as their weapons were laid down by militia groups the use of data capturing (biometrics) was carried out and exmilitants were registered and documented at various zones in each state accordingly. At the beginning, many had doubt about the whole amnesty deal despite assurance from some notable stakeholders, traditional and community leaders came out and convinced the ex-militants that the government was sincere in implementing the amnesty. To show it commitment, the late President in 2009 freed Henry Okah , a suspected leader of Movement of Emancipation of the Niger Delta (MEND) Okah accepted the amnesty offer after treason and gun running charges against him were dropped (The Guardian Newspaper, 2009; Aghedo, 2013).

Similarly, at the expiration of 60 day period 20,192 ex-militants disarmed and accepted the amnesty deal. In fact, as a result of the agitations by other militant youths 6,166 were added making it 26,358 recipients proclaimed by the president (The Nation Newspaper, 2013). It is necessary to know that sustainable peace and security will only thrive in the troubled region if there is the immediate stoppage and disruption of oil facilities which will lead to, and create an enabling environment in the area of infrastructural development. More so, the former agitators who keyed into the amnesty programme were accommodated and initially camped at designated centres temporarily at Aluu in Rivers State, Agbarho and Egbokodo all in Delta State before they were finally sent in batches to Obrubra (hub of the programme) to undergo transformational and rehabilitation/reintegration phase of the programme in order to re-orient and train them to acquire various skills in their different areas, (Ibude, 2011).

Similarly, the Federal Government earmarked for each ex-militants who have surrendered their arms and key into the post-amnesty programme with the payment of N65,000 monthly stipend for food and cash allowances during the post-amnesty rehabilitation period which is to last for three months as they would be deployed to designated training centres for rehabilitation programmes (Oluwaniyi, 2011; News watch Magazine, 2009).

Thus, after the amnesty proclamation in the region, it is clear that violence has reduced to an extent but not totally as crude oil production has risen to about 2.6 million barrels per day. What is responsible for this situation as the amnesty draws attention in the region is that there is no war and there is no peace and also, there is no winner and there is no loser in the conflict. Although, there is relative peace as oil production has increased the Nigeria foreign earning. Despite this the Niger Delta area still faces a lot of challenges.

\section{Impact of the Amnesty Programme}

According to Ajayi and Adesote (2013), there is no doubt that there are appreciable benefits or success of the amnesty deal initiated by President Musa Ya'Adua's Administration. The current state of security is attributed to amnesty programme particularly the DDR package. The amnesty package has been able to bring youth restiveness under control. The Amnesty involved surrender, demobilization, disarmament, and subsequent training of ex-militants. It has also been successful in bringing about a very significant reduction in the disruption of oil production and damage to facilities (Ikelegbe, 2014).

Presently, the amnesty package has brought about improvement in the lives of the ordinary people particularly the youths. In a way, amnesty has presented an opportunity to build capacity of the youths as well as reintegrate agitating youths of the Niger Delta into the mainstream in Nigeria as a confidence-building strategy while gradually addressing the root causes that necessitated the conflict in the first place, (Osah \& Amakihe, 2014). Oluduro \& Olubisi (2012), also stated that, if well implemented, the Amnesty programme could serve to negate the 'resource curse' theory in Nigeria that resource-rich economies such as Nigeria, Congo, Angola, etc. are more prone to mismanagement, underdevelopment and violence.

The Federal Government through the Presidential Amnesty Panel (PAP) has enlisted a total number of 30,000 exmilitants youths in the Niger Delta region. In 2009, the first phase incorporated into the prograamme was 20,192 exmilitants while in the second phase, it accommodated 6,166 ex-agitators and in November 2010 after the October 4, 2009 deadline another number of 3,642 persons have formed the third phase making it a total number of 30,000 ex-agitators now in the process (The Premium Times, 2012).

A major issue of the amnesty is that it did not follow any conventional method because the Federal Government 
did not officially declared war on the ex-militants in the region. This however seems not to be confirmed to the rules because the ex-militants who were involved in the criminal activities and other violent crimes are now regarded as freedom fighters by the people in the Niger Delta.

More importantly, there was no peace deal between the Federal Government and the ex-militant but what was seen is open negotiations. This approach/agreement mainly involved stakeholders and ex-militants ex-generals in the region. It is so because in a political amnesty there would have been negotiation between warring parties when there is no act of opponent defeat in any way. The conditions lay down would have been in an agreement of both parties (Singaporeanjbem.com). The presence of security personnel was also difficult to deal with effectively in the agreement as this would have given ex-agitators the ample opportunity to bring to the table before the government their grievance and demands accommodated in the peace agreement.

Again, there is also the issue of trust and sincerity between the militants and the Nigerian government which has not fully been addressed. It is on this note that the resources needed by the government and those needed by the people puts both interests at some conflict. This is however, between unequal parts, in which the superiority and prevailing presence of the government over the people of the Niger Delta places the latter at a very great disadvantage over the inhabitants (Omuta, 2014). Therefore, as a result of this the region is still underdeveloped and the locals in the region remain in abject poverty.

The Nigerian Government has not been trusted as regard this issue. For the government to be trusted, it means that the Niger Delta militants would be made to trust the Federal Government offer of amnesty. The question is, will they be convinced that the government has displayed some level of trust and sincerity in her past actions with them? The credibility of verbal communication with the people in the region and the ex-militants, and a standard of fairness in words and in deeds?

The answer to the question is that, the government can be found wanting for her level of trust. There is no doubt that it took the efforts of some stakeholders, governors, regional leaders among others for some of the ex-combatants to lay down their arms and embrace amnesty before deadline.

Also evident is the slow way and manner of response by ex-agitators to the amnesty and before the expiration of the deadline of October $4^{\text {th }} 2009$ the number of militants increased. About 15,260 ex-militants surrendered their arms and registered, the number of ex-militants later increased to 20,192 during the first phase of the programme, (Ehigiator, 2011). This is so because there may be an increase after the expiration of the deadline or a possible challenge having to do with documentation and authentication of the ex-militants in the region.

In addition, there are three components of the amnesty programme as encapsulated in the DDR framework which is also a basic principle of achieving peace, and it is an important element in post-conflict peace building at any level.

\section{DDR Programme in Post-Conflict Niger Delta}

\subsection{Disarmament}

The Disarmament process was majorly conducted by military personnel, the Nigerian Army (NA). Prior to the ex-militants being enlisted into the post-amnesty programme, large cashes of arms and ammunitions were stored in 82 Division of the Nigerian Army in Enugu State in compliance with the DDR code as spelt out by the United Nations (Nigeriamasterweb. com).

There are over 2,500 sophisticated guns 300,000 rounds of ammunitions lay down by 15,000 ex-agitators (Udegbunam, 2013). The arms surrendered also include a total number of 39,880 assorted arms and ammunitions and a breakdown include 482 automatic arms, 20,132 ammunitions, 295 magazines and 18,971 locally made guns which were recovered from ex-militants in Delta and Bayelsa State. Similarly, 82,406 ammunitions were recovered from Rivers States, 9,748 from Cross River, 9,725 from Ondo, 959 from Akwa lbom and 722 from Edo State (Uzodinma 2013). 


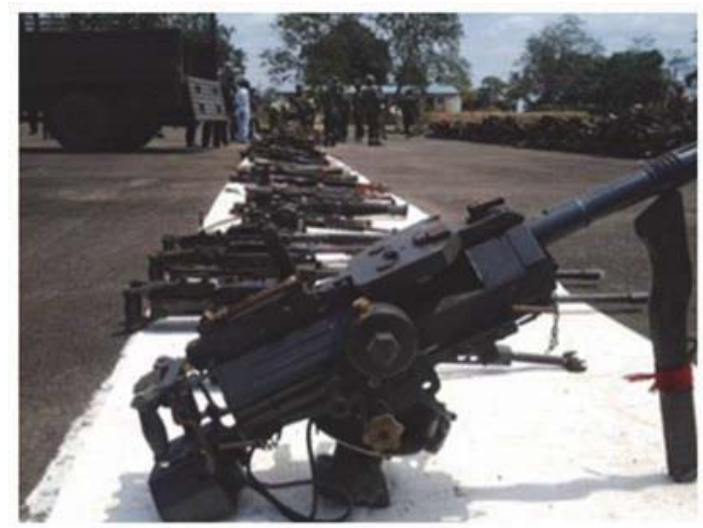

Figure 1: Truck load with arms and ammunition recovered from ex-militants and hand over to Nigerian Army in the Niger Delta.

Source: The Nigeria daily post, 2013

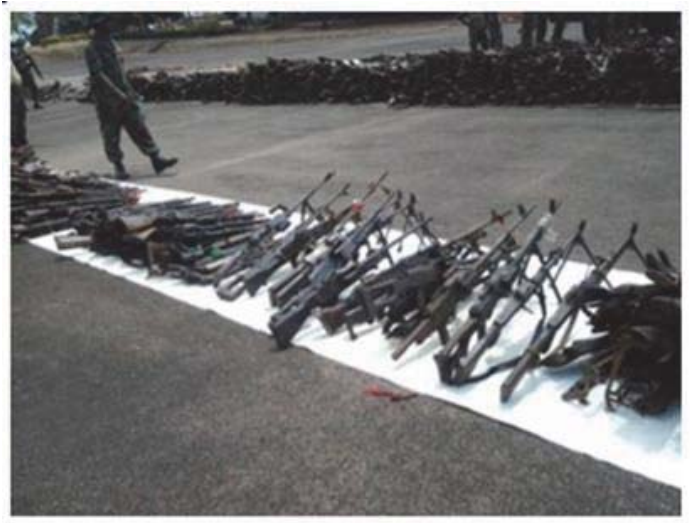

Figure 2: Assorted arms and ammunitions recovered from ex-militants displayed by Nigerian Army.

Source: Uzodinma, 2013

On the contrary, the arms and ammunitions surrendered by ex-militants are certainly low compared with the ones lay down at the screening centres. Despite these, there were series of attacks carried out by them during the disarmament exercise. The ex-agitators only surrendered few arms and ammunitions and the question is what happened to the remaining arms left? So long as the remaining arms are still at large there is the likelihood that the oil rich region remains unsafe and at risk of relapsing into violent conflict (Oluduro \& Olubisi, 2012:53).

\subsection{Demobilization}

The demobilization process proceeds reintegration and this is the second components of the DDR programme. The process involved identification, biometrics, documentation and the verification of ex-militants who were in designated camps for the Amnesty Programme. The prorammme made available monthly stipends for each agitator. During the process the Aluu camp was the designated centre for the disarmament which could only accommodate not more than 800 out of an estimated 700 ex-militants, (Ikelegbe, 2010). There were also shortage of bed space and facilities for 
accommodation that were only made for few due to the poor organization and supervision and most of the centre for rehabilitation were empty and not in use simply because of the accommodation system.

The demobilization camp for disarm ex-militants was the Obruba camp where ex-militants had non-violence transformational training and re-integration programme. Security in the camp was tight as security agents numbering about 200 with 13 Amphibious Brigade, 120 Soldiers, 60 mobile policemen, 20 conventional policemen and 10 Nigerian Security and Civil Defence Corps (NSCDC). The process involves thorough screening of ex-militants by security personnel before they go in to make sure that no one enters the camp with arms and ammunition and, to ensure a smooth demobilization process during this period.

Subsequently, the camp is not devoid of protest and agitation registered in some quarters including Benin/Port Harcourt as a result of the poor facilities and accommodation, poor conditions of living, unpaid stipends and allowances, and neglect of ineffective rehabilitation programmes. The process did little to remobilize them as ex-militants were sent back after weeks to be reintegrated into the larger society.

\subsection{Reintegration}

The reintegration and reinsertion phase by PAP was important to train ex-agitators having gone through transformational training. These training include vocational skills, entrepreneurial training and development, technical capabilities, formal educational and an opportunity for them to be employed as many ex-militants were offered to work as change agents in a larger community.

More importantly, the programme is in two phases. The first phase is the rehabilitation programme as ex-militants were over 19,000 who were trained in Obruba Camp that lasted for about 3 to 18 months. They taught them violent conflict and non-violent method and, they were also taught about conflict management in general as a tool for peace with the aid of a councilor. The following is a breakdown of ex-militant trained at Obruba Camp with Rivers state had the highest

Table 1: Ex-militants trained in Obruba Camp in Rivers state

\begin{tabular}{|c|c|c|}
\hline S/N & States & No. of ex-militants \\
\hline 1. & Rivers & 7,015 \\
\hline 2. & Bayelsa & 6,793 \\
\hline 3. & Delta & 3,320 \\
\hline 4. & Ondo & 1,303 \\
\hline 5. & Edo & 459 \\
\hline 6. & Akwa Ibom & 188 \\
\hline 7. & Cross Rivers & 172 \\
\hline \multicolumn{2}{|c|}{ Total } & 19,576 \\
\hline
\end{tabular}

Source: Ujah 2011.

The second phase includes counseling to aid ex-militants psychologically where they decide on the kind of vocation or educational training they would embark on (Udegbunam, 2013). The programme also help them in areas like; sea fairing, piloting, ICT, ocean diving as those who have the interest of going back to school were also giving the opportunity to study in vocational or educational training in countries such as United Arab Emirate, Ghana, Israel, Russia, Ukraine, Philippines, India, Sri-Lanka, Malaysia, South Africa, Singapore and others. The programme also includes helping exmilitants granting them capital and other necessary assistance. It is also necessary to know that a couple of ex-militants are still being trained at home and abroad.

\section{Revisiting Peace Building Efforts in Post-Conflict Niger Delta}

The amnesty is one of the successful intervention programme since independence. With efforts from PAP, no fewer than 834 were enrolled in about 100 higher institutions in Nigeria and abroad. In the 2013 academic session, 459 ex-militants are also in some private universities across the country (The Nigerian leadership, 2014).

In 2013, 2,400 ex-agitators were successfully deployed to vocational training centres within and outside the country as part of the reintegration and rehabilitation process (Folami, 2014). In 2014, as part of the PAP programme, 6,000 ex- 
militants would be trained while another 6,000 would also be trained in 2015 (Okpi, 2014). Through the PAP a total number of 3,482 persons benefitted through the programme in about 77 training centres in Nigeria while those in abroad includes a total number of 5,217 ex-militants.

According to Nnaike (2013) in four years, the scheme has also graduated 9,192 from the training skills programme in various fields such as in electrical installation, carpentry, plumbing, welding and fabrications to mention amongst others.

Table 2: Ex-militants trained in vocational skills

\begin{tabular}{|c|c|c|}
\hline S/N & Skills & Numbers \\
\hline 1. & Agriculture & 239 \\
\hline 2. & Automobile & 207 \\
\hline 3. & Welding and Fabrication & 2,204 \\
\hline 4. & Entrepreneurship & 2,2798 \\
\hline 5. & Carpentry and Plumbing & 298 \\
\hline 6. & Oil Drilling and Marine & 916 \\
\hline 7. & Electrical Installation & 89 \\
\hline 8. & ICT & 273 \\
\hline 9. & Crane and heavy duty machine & 1,030 \\
\hline 10. & Boat building & 299 \\
\hline 11. & Pipe fitting & 250 \\
\hline 12. & Entertainment & 60 \\
\hline 13. & Others & 618 \\
\hline & Total & 9,192 \\
\hline
\end{tabular}

Source: Ikelegbe \& Umukoro 2014:38

More so, 2,204 have graduated from small scale business or entrepreneurship training, 2,798 from oil drilling while 916 from marine engineering courses and programmes. The graduates who were engaged in boat building are 299 , crane and heavy duty were 1,030, and agriculture 239 (Ikelegbe \& Umukoro, 2014). While in 2014 PAP has produced a number of 66 airplane and helicopter pilots and 61 aviation maintenance engineers trained in parts of Europe, Africa and Asia.

The Federal Government through the Presidential Amnesty Office (PAO) has liaise with some individuals, private bodies and organization at home and abroad to employ ex-militants after a successful training in various skills acquisition programme to enable them to earn a living. In its efforts, 10 ex-militants were employed with the Nigerian Army, 6 with the Nigeria Customs Service, 5 with SAP Drilling Oil And Gas Limited while 29 of them have been given automatic employment for a successful completion of their courses by Schlumberger (Obia, 2014).

Also, in a similar vein, a total number of 113 ex-militants had been engaged. 40 maritime trainees were employed by Century Energy Group, 4 were employed by Plant and Processing Service Company all in Nigeria, while 5 were offered jobs in South Africa by Ashland investment Service, 10 were given employment by Learning Resources in Ghana, 30 were offered employment in Dubai for their exceptional conduct and performance while another 24 were offered employment as maritime trainee (The Vanguard, 2012).

\section{Major Challenges Confronting Post-Conflict Peace Building}

It is expected that this package would bring about security and sustainable peace in the troubled areas as many nations are buyer of Nigeria crude oil. However, the hope and expectation of the programme is becoming unrealistic owing to the numerous challenges.

There was the issue of inadequate provision or arrangement for ex-agitators. As a matter of fact, they complained of feeding and non-payment of housing allowance as the living condition and other facilities also led to some protest in some part of the state where ex-combatant were asked to return to their camp until the centre is put in order (Ameh, 2013).

There is also the issue of poor management that manifest itself into corruption and embezzlement of funds. Apart from corruption, some amnesty officials politicize the programme while several ex-generals short-changed their boys and serve as link to banks. For instance, according to an ex-militants, we get the sum of N10,000 which is not enough for our up keep. Also, foot soldiers are paid through the commanders and they are paid little stipend (Eno-Abasi, 2011). 
Recently, it was reported that 13 ex-combatants (Nigerian Amnesty pilots) who are currently undergoing training at Lufthansa Flight Training School in Germany have been sent home for non-payment of fees. This is as a result of their inability to pay sundry fees as stipulated in their training manual (Daniel, 2015).

Most recently, in a bid to put an end to corruption the Economic and Financial Crime Commission (EFCC) has started probing the activities of the PAP and has invited Kingsley Kuku the immediate past Special Adviser to President on Niger Delta Affairs over the allegation of diverting of public fund running into millions of Naira (The Vanguard, 2015).

\section{Security Implications of the Challenges}

As opined by Aghedo (2013), the death of Yar Adua has an adverse effect on the success of post amnesty programme as Niger Deltans turned the good dream of the president into private business to enrich themselves and politicize it. The ex-militants operate divide and rule tactics among themselves while others were neglected from the scheme of things. The resurgence of militancy also led to an upsurge of various criminal activities such as arm robbery, oil theft, sea piracy, pipeline vandalisation, bombings and most especially hostage taking.

Although, armed robbery, kidnapping and crude oil theft has been the order of the day. For example, on 24 November 2011, a former ex-militant engaged in a robbery operation around Tombia Avenue, GRA, Rivers States was killed, according to the State Police Public Relations Officer, (The Vanguard, 2011). Kidnapping became a daily activity despite government efforts to curb the menace. In 2010, no fewer the 19 persons comprising of 12 Nigerians, 2 Americans, 2 French nationals and 2 foreigners were abducted. Kidnapping for money has now become a fast way of becoming rich in the society. Though recently, there is a decline in violence but there is increase in emergence of illegal refineries as the rate at which crude oil theft popularly known as "oil bunkering" has drastically increased has caused more environmental hazard in the area (The Nation Newspaper, 2015).

However, the rate at which crude oil theft popularly known as "oil bunkering" has drastically increased. It is reported that in 2000 petroleum product were stolen daily in large quantities (www.adakaboro.org). In 2001, the figure rose to 7244,171 barrels per day while in 2013 , it was noted that apart from oil theft, pipeline vandalization and other related activities associated with oil bunkering as the Federal Government of Nigeria and other oil servicing companies may be losing over N100 billion about (US\$ 770) if not properly managed (Falobi, 2014). This amount is lost annually to fraud and illegal oil bunkering.

Also, some criminals bore holes on pipelines installations scup fuel others tap from well heads leading to oil spills and in most cases disrupt the flow of petroleum products. Recently, the JTF spokesman confirmed that it has destroyed about 308 illegal refineries, 30 barges, 115 smuggling boats, 20 tankers trucks, 566 surface tanks, 275 drums of illegal refined petroleum products, 273 pumping machines and 2 outboard engines in the process while some suspects were arrested in connection with crude oil theft (Odiegwu, 2014).

The water ways are major risk as a result of sea piracy and other criminal activities. Most importantly, in Robot creeks in Nembe, Bayelsa State a gang of oil sea pirates fled with various degrees of injuries as a result of gunshots from soldiers patrolling the creeks in the region. Also, in Okpoko Creeks in Delta State, 9 Cotonou Boats with stolen crude oil were recovered from sea pirates , 7 speed boats loaded with 75 jerry cans containing illegal refined Automated Gas Oil (AGO) and 5 pumping machines was recovered (The Nigerian times, 2014).

Apart from stipend of ex-militant that causes disturbances in these areas, there was also protest on exclusion by restive youths. There have been complaints that many ex-combatants were excluded even after submitting arms particularly in the phase two and three. There was also claim that the distribution of reintegration slots among ex-militants groups and camps was inequitable. Some ex-militants leaders and ex-militants camps alleged to be given preferential treatment in the selection of ex-combatants for demobilization and reintegration as well as payments of reinsertion. There were protests among the ex-generals that their camps were allocated very few slots for monthly stipend relative to the number of persons who surrendered and the arms dropped in the third phase of the Amnesty in Edo and Delta State.

In yenogoa, December 2014 they barricaded the road, disrupt public peace, stopped vehicular movement, and vented anger on innocent member of the public and thereby paralyzing business activities (Utabor, 2014). Generally, this has negative effect on the people as most of the issues being generated by militancy have not been met as communities and youths seek for redesign, extension of the programme beyond 2015, (The Nation Newspaper, 2015).

\section{Government Efforts in Niger Delta}

It is germane to know that successive administrations have come out with various developmental programmes at all levels, the private sector, individuals, religious bodies and developmental partners over the years. Yet the development 
challenges persist. This is so because of the conflict which has not regenerate the degraded environment and have not provided succor to the locals either in terms of economic empowerment or development to mitigate excruciating conditions.

Following the Willinks report/recommendation that gave special attention for the establishment of some agencies, it however came up with other various progrmmes that either did little or were poorly funded. Such programmes include: Niger Delta Development Board, Niger Delta Basin Development Authority (NDBA), Oil Mineral Producing Area Development Commission (OMPADEC) and more recently the Niger Delta Commission (NDDC). "The NDDC which has the potential to offer a lasting solution to the difficulties of the region, which successive governments have grapple with even before independence" (Jebbin \& Wilson, 2009). After eleven years NDDC has been established, crime continues to increase, poverty level was still high and environmental degradation/pollution continued unabated. Also, the government not too long created the Ministry of Niger Delta Affairs to meet the demands of the people in fast tracking development in the region.

Without doubt, Niger Delta amnesty and peace building programme presents some great merits. What is rather doubtful is whether the ex-militants surrendered all arms in their possessions, as is the case with most threat from militant's ex-generals, (Muggah \& Batchelor, 2002; Gilbert, 2010).

A major criticism however is that, has amnesty and peace building been able to address the root cause of the conflict; basic socio-economic and environmental needs in the Niger Delta region (Bakare, 2014). There is no doubt that the Niger Delta amnesty and peace building as such, may not be different from past amnesties such as the one offered to Isaac Boro by General Gowon, a Niger Delta revolutionist that fought against the Nigerian government and the Biafran war lords and the after the Nigeria-Biafra War (1967-1970) or the many presidential pardons granted political prisoners since independence. The failure in satisfying and ameliorating the plights of the people could potentially undermine the adjudged success of the amnesty deal and peace building in the post conflict region (Oluduro \& Olubisi, 2012).

\section{Conclusion}

The study critically looked at amnesty programme, the cause, impacts and its implication. Efforts were also made at revisiting its corollary the DDR programme. It is apparently clear that there was disruption of pipeline by ex-militants which adversely affected the Nigeria economy. This undermines sustainable peace and development and constitutes serious threat to the Nation. This reveals oil disruption which is not of benefit to Nigeria government, where there is infrastructural decay, marginalization and the widespread unemployment and uneven distribution of resources in the region. What is experience is a graveyard peace. In addition, it explored the efforts of successive Nigeria government in trying to established different projects/commission to solve the Niger Delta problems yet, peace remain elusive in the region. This paper also observed that until the root cause of the conflict is addressed there will not be stability and development in Niger Delta.

\section{References}

Aghedo, I .(2013). Winning the War, Losing the Peace: Amnesty and the Challenges of Post-Conflict Peace-Building in the Niger Delta, Nigeria. Journal of Asian and African Studies 48:267

Ajayi, A.I \& Adesote, A.S (2013). The Gains of the Amnesty Programme in the Niger Delta Region of Nigeria, 2007-2012: Preliminary Assessment. Journal of Asian and African Studies. Vol 48. No. 4 506-520

Akpan, A. (2010). Government's team warns politicians against recruiting ex-militants. The Guardian, 19 October

Ameh, C. G. (2013). Amnesty: Fear Grips Presidency as Niger Delta Militants Plan to Invade Abuja. Daily Post,8 October.

Bakare, I. (2014). Governance, poverty and natural resources management. A case study of the Niger Del, University of Bradford.

Daniel. S. (2015). Lufthansa sacks 13 Nigerian Amnesty pilots. The Vanguard, 21 July. http://www.vanguardngr.com/2015/07/lufthansasacks-13-nigerian-amnesty-pilots/ Accessed 21/7/2015

Ehigiator, K. (2011). Amnesty: Nigeria's gift to the world. The Vanguard, 30 September http://www.vanguardngr.com/2011/09/amnestynigeria\%E2\%80\%99s-gift-to-the-world/Accessed 27/11/2014

Eno-Abasi, S. (2011). Rumbling in campmover pay. The Guardian, 25 May

Falobi, F. (2014). Alamiesiegha on oil bunkering. The daily independent 4 April https://www.google.com.ng/?gfe_rd=cr\&ei=KoERVe2 cEciH8Qf614HYDA\&gws_rd=ss/\#nfpr=1\&q=daily+independent+2014+Alamieyeseigha+on+oil+bunkering\&spell=1.Accessed 2/12/2014

Federal Governmnt of Nigeria (2009). About the Amnesty Programme. Availableat; http://www.nigerdeltaamnesty.org/index.php?option= com_content\&view=articleid=4 (Accessed 12/11/2014)

Folami, D. (2014). Federal Government To Spend N35.83bn Ex-militants This Year. http://www.theinfostride.com/2014/02/federal-govtto-spend-n35-83bn-on-ex-militants-this-yearl Accessed 18/12/2014 
Gilbert, L.D. (2010). Youth Militancy. Amnesty and Security in Niger Delta Region of Nigeria.

Ibude, S.E. (2011). An Evaluation of the Presidential Amnesty Programme for the Niger delta Militants in Nigeria; Implications for Peace and Hydro- Carbon Production in the Oil- Rich Region. A Research Proposal Presented to the Department of Political Science and Public Administration, University of Benin, Benin City.

Ikelegbe, A. (2010). Oil, Resource Conflict and the Post Conflict Transition in the Niger Delta Region: Beyond the Amnesty. CPED Monograph Series No. 3

Ikelegbe, A. (2014). The Role of the Delta State Government in the Management of the Amnesty Programme, Nigeria Stability and Reconciliation Programme (Nsrp) Policy Briefs No [3]

Jebbin, M.F \& Wilson, G. (2009) Niger Delta development commission and development of the delta region: A mirage. Journal of Globalization and Development in Africa, Vol. 2, No.2

Jegede, M. (2013) Evaluating the amnesty programme http://www.nationalmirroronline.net/new/evaluating-the-amnesty-programme/ Accessed 13/8/2014

Ikelegbe, A \& Umukoro, N. (2014). Exclusion and the Challenges of Peace Building in the Niger Delta: An Assessment of the Amnesty Programme CPED Monograph Series No. 11

Kuku, K. (2012). Ex-militants and the Amnesty Programme http://www.thenigerianvoice.com/news/96900/1/kuku-ex-militants-and-theamnesty-programme.html 24 August,2012. Retrieved 28/6/2015

Muggah, R \& Batchelor, P. (2002). Development held Hostage. Assessing the effects of small arms on human development and development linkages of small arms proliferation, availability and use. New York.

Nnaike, U. (2013). Amnesty Programme Produces 91,92 Graduates in Four Years. This day 25 June http://www.thisdaylive.com/articles/ amnesty-programme-produces-9-192-graduates-in-four-years/151464/ Accessed 18/12/2014

Obia, V. (2014). Ex-militant get Schlumberger Job. The Punch March 10

Odiegwu, M. (2014). JTF destroy 308 illegal refineries. The Nation March 10

Okpi, A. (2014). FG spends N260bn ON 30,000 ex-militants. The Punch February 16. http://www.punchng.com/news/fg-spends-n260bnon-30000-ex-militants/ Accessed 14/12/2014

Okonta, I. (2013). Nigeria: Policy Incoherence and the Challenge of Energy Security. The Handbook of Global Energy Policy.

Oluduro, O. \& Olubisi, F.O. (2012). Nigeria: In Search of Sustainable Peace in the Niger Delta through the Amnesty Programme. Journal of Sustainable Development; Vol. 5 No. 7

Olukoya, S. (2009). Slow start for Niger Delta Amnesty. http://www.ipsnews.net/2009/08/nigeria-slow-start-for-niger-delta-amnesty/ Retrieved 30/6/2015

Oluwaniyi, O. (2011). Post Amnesty Programme in the Niger Delta: Challenges and Prospects in Conflict Trend (46-54).

Omuta, G.E.D. (2014). Transitioning to Sustainable Development and a Green Economy in the Niger Delta of Nigeria: Challenges and Prospects. CPED Monograph Series No. 9

Osah, G. \& Amakihe, B. (2014). War- to-Peace Transition in the Niger Delta: Is Amnesty Working, IOSR Journal of Economics and Finance, Volume 5, Issue 5. PP 01-07

The citizen (2013). FG plan more programmes for ex-militants in the Niger Delta 1 September. http://www.thecitizenng.com/ governance/fg-plans-more-programmes-for-ex-militants-in-niger-delta/ Accessed 12/12/2014

The Guardian Newspaper (2009) http://www.theguardian.com/world/2009/aug/06/niger-delta-militants-amnesty-launched Accessed 3/12/ 14

The Nation Newspaper (2013) Rumbling in the creeks, http://www.nationonlineng.net/new/amnesty-rumblig-in-the-creeks-2/Amnesty: 24 February. Accessed 15/6/2015

The Nation Newspaper (2015) Researchers seek redesign, extension of Amnesty Programme. http://www.thenationonlineng.net/ new/researchers-seek-redesign-extension-of-amnesty-programme. 12 June. Accessed 17/6/2015

The Newswatch Magazine (2009). Report of the technical committee on the Niger Delta, 4 May

The Nigerian leadership (2014). FG To Spend N35.83bn on Ex-militants In 2014-kuku, 28 February http://www.leadership.ng/news/ 350382 Accessed 12/12/2014

The Nigerian Times (2014). Sea piracy: Three shot dead, solders injured as JTF fight off attacks, 24 June.

The Premium Times (2012). Nigeria enlists 30,000 ex-militants in Presidentail Amnesty Programme, says kuku, 24 December http://www.premiumtimesng.com/news/112493-nigeria-enlists-30000-ex-militants-in-presidential-amnesty-programme-sayskuku.html.Accessed 13/8/2014

The vanguard (2012). 113 ex-militants offered employment in Nigeria, abroad-says amnesty office, 28 November

The Vanguard (2014) Ex-militant killed by police during a robbery operation in Rivers state, 24 November

The Vanguard (2015) EFCC to probe Amnesty Programme. http://www.vanguardngr.com/2015/efcc-to-probe-amnesty-programme 24 July.

Ubhenim,O.E, (2013), The Federal Government's Amnesty in the Niger Delta: An Appraisal. Cilt II, Sayl,ss. 179-203

Udegbunam, K.C.W. (2013), Repositioning Nigeria's Amnesty Programme for Conflict Transformation and Post-Conflict Peace-Building in the Niger Delta Region of Nigeria. Singaporean Journal of Business Economic, and Management Studies Vol.2, No.1

Ujah, E. (2011). Amnesty ends in 2015. The Vanguard 9 September. http:// www.vanguardngr.com/2011/09/amnesty-ends-2015-kuku/ Accessed 27/11/2014

Utabor, S. (2014) Ex-militants protest non-payment of allowance in Bayelsa, The Punch 18 December. http://www.punchng.com/news/ ex-militants-protest-non-payment-of-allowances-in-bayelsa/ Accessed 24/3/2014 
Uzodinma, E, (2013). Amnesty: Task force hands over 39,880 assorted arms and ammunition to Nigeria Army. The Daily post 16, March. http://www.dailypost.ng/2013/03/16/amnesty-task-force-hands-over-39880-assorted-arms-and-ammunition-to-nigerianarmy/Accessed 27/11/2014

Watt, M. (2007), Petro-insurgency or criminal syndicate? Conflict and violence in the Niger Delta. Review of African Political Economy 34(114).

www.adakaboro.org Accessed 24/6/2015

www.businessday online.com/2013/04 youth empowerment. Accessed13/6/2015

www.nigeriamasterweb.com/Blog/Index.Php/2012/04/25/Masterweb/press-release-the-amnesty-office-is-not-a-security-outfit. Accessed $16 / 6 / 2015$.

www.singaporeanjbem.com/pdf/SG-Vol 2-(1)/5.pdf 2013. Accessed 20/5/2015

www.dlc.dlib.indiana.edu,/dlc/bitsream/...WG26_Okontoni,olu.pdf?sequence=1 Building and sustaining peace and security in multiethnic Nigeria. Retrieved 24/06/2015 